\title{
Pembelajaran Sejarah Berbasis Nilai-nilai Serat Wedhatama untuk Menumbuhkan Etika dan Moral Siswa
}

\author{
Renny Pujiartati1 ${ }^{1}$, Hermanu Joebagio² ${ }^{2}$, Sariyatun ${ }^{3}$ \\ 1Mahasiswa Magister Pendidikan Sejarah, Universitas Sebelas Maret, Surakarta \\ 2Profesor Magister Pendidikan Sejarah, Universitas Sebelas Maret, Surakarta \\ 3Profesor Magister Pendidikan Sejarah, Universitas Sebelas Maret, Surakarta \\ 1rennypujiartati31@gmail.com, 2hermanu.joebagio@gmail.com, 35ari_fkip_uns@yahoo.co.id
}

\begin{abstract}
Serat Wedhatama is a serat that is written by Mangkunegara IV, where in there are the cultural values of their nation. Their culture is then necessary to transform students through education, in particular the historical studies. This paper is a part of Research and Development $(R \& D)$ using the model of the Borg \& Gall development model oriented learning history based Serat Wedhatama values to improve ethics and morals in students and habitual in educational institutions. In the first stage measures undertaken include: (1) the mapping ethical values and morals in the Serat Wedhatama through the process of hermeneutics; (2) a description of the learning history at State High School 5 Surakarta; (3) the formulation of draft models learning history based Serat Wedhatama values. The results of this study are: (1) produce deconstruction of ethical values and morals in Serat Wedhatama, (2) description of the condition of learning history at a high school in Surakarta, (3) a draft model of a learning history based values of Serat Wedhatama.
\end{abstract}

Keywords: Ethics, Morals, Serat Wedhatama, Character Building.

\begin{abstract}
ABSTRAK
Serat Wedhatama adalah serat yang ditulis oleh Mangkunegara IV, dimana di dalam nya terdapat nilai-nilai budaya bangsa yang adiluhung. Budaya yang adiluhung ini kemudian perlu ditransformasikan pada siswa melalui pendidikan, khususnya pembelajaran sejarah. Tulisan ini adalah bagian dari Research and Development (R\&D) menggunakan model Borg \& Gall yang berorientasi pada pengembangan model pembelajaran sejarah berbasis nilainilai Serat Wedhatama untuk meningkatkan etika dan moral pada siswa dan dihabituasikan dalam lembaga pendidikan. Pada tahap pertama langkah yang dilakukan meliputi: (1) pemetaan nilai-nilai etika dan moral dalam Serat Wedhatama melalui proses hermeneutika; (2) deskripsi pembelajaran sejarah di SMA Negeri 5 Surakarta; (3) perumusan draf model pembelajaran sejarah berbasis nilai-nilai Serat Wedhatama. Hasil penelitian ini yaitu: (1) menghasilkan dekonstruksi nilai-nilai etika dan moral dalam Serat Wedhatama, (2) mendeskripsikan kondisi pembelajaran sejarah di SMA Surakarta, (3) draf model pembelajaran sejarah berbasis nilai-nilai Serat Wedhatama.
\end{abstract}

Kata Kunci: Etika, Moral, Serat Wedhatama, Pembentukan Karakter.

\section{PENDAHULUAN}

Globalisasi menyeret masyarakat Indonesia ke dalam budaya individualis. Budaya bangsa Indonesia berbasis gotong-royong, sementara budaya individualis meretakkan relasi sosial.
Globalisasi menimbulkan pergeseran nilai budaya. Pertemuan antara arus budaya global dan lokal menyebabkan ketidakseimbangan dan kegelisahan dalam masyarakat, sehingga muncul keinginan untuk mempertahankan 
budaya lokal, sebagaimana dijelaskan Waters:

“...contested and undecided...encounter between global cultural flows and inherited local identities,...the uneasy balance between the persistence of unique local cultural identities and the reshaping of such uniqueness by totalizing transnational cultural" (Waters, 1995: 130).

Globalisasi mengabaikan budaya setempat. Hal ini menjadi tantangan baru dalam pembentukan jati diri bangsa Indonesia di lembaga pendidikan. Guna mengurangi pengaruh globalisasi, perlu dihidupkan kembali nilai-nilai adiluhung bangsa, yang di dalamnya terdapat budaya dan tradisi lokal.

Krisis moral yang terjadi akhir-akhir ini, yang meliputi pelecehan dan kekerasan seksual, kenakalan remaja, korupsi, dan sebagainya adalah implikasi dari penurunan moralitas remaja. Remaja semestinya mendapatkan pendidikan moral secara baik di lembaga pendidikan. Hingga detik ini juga masih sering terjadi konflik horizontal berbau suku, ras, agama dan golongan (Setiawan, 2016:11). Permasalahan tersebut menjadi masalah sosial yang hingga saat ini belum bisa diatasi secara tuntas.

Pendidikan merupakan salah satu lembaga yang seharusnya sebagai penjaga nilai-nilai moral telah mengalami degradasi (Wibawa, 2010:
72-73). Beberapa kasus kecurangan dan pelanggaran norma-norma kejujuran di sekolah, misalnya mengejar nilai UN, melakukan manipulasi nilai adalah salah satu tindakan yang mengesampingkan nilai moral (Zubaedi, 2011: 3).

Kondisi krisis dan dekadensi moral ini menandakan bahwa seluruh pengetahuan agama dan moral yang didapatkan di bangku sekolah belum terserap dengan baik oleh peserta didik. Demoralisasi terjadi karena proses pembelajaran yang cenderung mengajarkan pendidikan moral dan budi pekerti sebatas teks dan belum memberikan arti terhadap kehidupan sosial peserta didik. Dengan begitu ada indikasi simpul yang salah dalam pewarisan nilai-nilai budaya yang adiluhung. Oleh karena itu, dibutuhkan reinforcement moral budaya lokal yang dipandang lebih aplikatif untuk menuntun kecerdasan spiritual dan moral.

Peserta didik mempunyai stabilitas mental untuk menghadapi globalisasi. Pendidikan memiliki kontribusi yang luas dalam memberikan solusi terhadap krisis dan dekadensi moral. Sebagaimana dijelaskan oleh Lickona (2013:55) bahwa sekolah mempunyai peranan penting dalam menyampaikan nilai-nilai etika dan moral. Nilai-nilai etika dan moral tersebut dipahami, dihayati dan kemudian diaplikasikan dalam tindakan. 
Oleh karena itu, lembaga pendidikan sebagai instansi yang berperan penting dalam menghadapi tantangan globalisasi diharapkan berpartisipasi dalam menangani masalah-masalah pada abad modern ini.

Menghadapi krisis dan dekadensi moral dapat diantisipasi melalui pewarisan luhur moral bangsa Indonesia yang tidak ternilai harganya. Kekayaan budaya yang dimiliki bangsa Indonesia, seharusnya menjadi cerminan perilaku dan cara berpikir yang positif masyarakat Indonesia (Setiawan, 2016:11). Kekayaan nilai-nilai kearifan lokal yang berupa ajaran moral, kebijakan hidup dan keteladanan tersimpan dalam Serat Wedhatama yang merupakan karya Mangkunegara IV.

Nilai-nilai moral yang berkembang saat ini adalah nilai-nilai moral yang universal berasal dari budaya Barat. Oleh sebab itu, dibutuhkan nilai-nilai moral yang berlandaskan pada budaya bangsa yang adiluhung yang sesuai dengan karakter bangsa Indonesia. Nilai-nilai moral dalam Serat Wedhatama adalah nilai-nilai moral yang khas dengan budaya bangsa Indonesia. Dekonstruksi Serat Wedhatama perlu dilakukan untuk diwariskan kepada peserta didik dan diimplementasikan dalam pembelajaran sejarah sebagai strategi penguatan character building untuk generasi muda. Pengembangan model pembelajaran sejarah berbasis Serat Wedhatama adalah upaya yang dilakukan untuk membentuk identitas bangsa. Pada umumnya masa remaja adalah masa pencarian jati diri. Penanaman nilai-nilai Serat Wedhatama dalam proses pembelajaran menghindari terbentuknya kepribadian yang sakit (Froman, 1996). Dengan hilangnya pribadi yang sakit, maka character building pun semakin kuat.

Istilah history diambil dari historia dalam bahasa Yunani berarti informasi atau penelitian yang ditujukan untuk memperoleh kebenaran (Kochar, 2008:1). Kuntowijoyo (2005:18) menjelaskan sejarah sebagai hasil rekontruksi masa lalu. Helius (1993:5) menjelaskan bahwa sejarah berarti cerita atau kejadian atau peristiwa yang benarbenar sudah terjadi atau berlangsung pada waktu yang lalu, yang telah diteliti oleh penulis sejarah dari masa ke masa. Daliman (2012:56) menjelaskan tujuan pengajaran sejarah di sekolah adalah agar siswa memperoleh kemampuan berpikir historis dan pemahaman sejarah.

Dudung (2007: 14) menjelaskan sejarah adalah sebuah ilmu yang berusaha untuk menemukan, mengungkapkan, serta memahami nilai dan makna budaya yang terkandung dalam peristiwa-peristiwa masa lampau. Grant Bage (1999:38) menjelaskan 
bahwa pembelajaran sejarah tidak hanya berkaitan dengan transmission of values dan transmission of knowledge, tetapi juga sebagai "building character, feeding the mind and the emotions, linking us to life, linking us to our past, helping adults and children to communicate, helping children develop skills, and inspiring to greatness". Rincian fungsi yang dikemukakan Grant Bage dipersepsikan sebagai paradigmatik pembelajaran reflektif (Garg, 2007: 148-150), sebab proses kegiatan pembelajaran itu diarahkan untuk melakukan eksplorasi terhadap networking collective memories (Joebagio dalam Garvey, B. \& Mary, 2015: ix-xiii). Melalui pembelajaran yang reflektif dan networking collective memories seseorang memperoleh inspiring to greatness untuk membentuk karakter pada siswa.

Tujuan pembelajaran sejarah menurut Kuntowijoyo (2005: 18) secara umum sejarah mempunyai fungsi pendidikan yaitu sebagai pendidikan moral, pendidikan penalaran, pendidikan politik, pendidikan untuk perubahan, pendidikan untuk masa depan, dan keindahan. Hubungan erat antara sejarah dengan pendidikan kemudian diperlukan proses aktualisasi nilai-nilai sejarah dalam kehidupan nyata. Dengan kata lain, sejarah tidak berfungsi bagi proses pendidikan yang menjurus kearah pertumbuhan dan karakter bangsa apabila nilai-nilai sejarah tersebut belum terwujud dalam pola-pola perilaku yang nyata.

Sejarah mempunyai guna edukatif karena sejarah dapat memberikan kearifan bagi yang mempelajarinya. Sejarah yang memfokuskan perhatian pada masa lampau tidak dapat dipisahkan dari masa kinian, karena semangat dan tujuan mempelajari sejarah ialah nilainya yang dapat diimplementasi di masa kini. Hal ini tersirat dari kata-kata Croce bahwa "all history is contemporary history", yang kemudian dikembangkan oleh Carr bahwa sejarah adalah "unending dialogue between the present and the past" (Widja, 1988:49-50). Berdasarkan pernyataanpernyataan di atas, dapat disimpulkan bahwa apabila kita dapat memproyeksikan masa lampau ke masa kini, maka kita dapat menemukan makna edukatif dalam sejarah. Dalam kaitannya dengan guna edukatif dan inspiratif dari sejarah, dapat dikemukakan bahwa sejarah memiliki kaitan yang sangat erat dengan pendidikan pada umumnya dan pendidikan karakter pada khususnya. Melalui sejarah dapat dilakukan pewarisan nilai-nilai generasi terdahulu ke generasi masa kini. Proses pewarisan nilai-nilai itu menumbuhkan kesadaran sejarah yang pada gilirannya dapat dimanfaatkan untuk pembangunan watak bangsa/ nation character building. 
Kedudukannya yang penting dan strategis dalam pembangunan watak bangsa merupakan fungsi yang tidak dapat digantikan oleh mata pelajaran lainnya.

Kekayaan budaya yang dimiliki bangsa Indonesia, seharusnya menjadi cerminan perilaku dan cara berpikir positif manusia Indonesia (Setiawan, 2016: 11). Kekayaan nilai-nilai kearifan lokal berupa ajaran moral yang tersimpan dalam karya sastra lama. Ajaran dalam karya sastra banyak mengandung ajaran moral, kebijakan hidup, yang di dalamnya penuh dengan keteladanan. Latief (2009: 85) menjelaskan pengaruh kesusastraan terhadap kehidupan tidak bisa diremehkan. Tokoh-tokoh dalam karya fiksi sering sekali mempengaruhi hidup dan standar masyarakat. Salah satunya adalah karya sastra Jawa yang mengandung ajaran moral, yaitu Serat Wedhatama karya Mangkunegara IV. Setting sosial pada masa Kanjeng Gusti Pangeran Adipati Arya Mangkunegara IV mengalami dekadensi moral yang terjadi di masyarakat sehingga mendorong Mangkunegara IV menulis serat piwulang (Vina, 2010: vii). Serat piwulang adalah karya sastra yang di dalamnya terkandung ajaran moral dan sikap hidup (Sudewa, 1991:3). Melalui implementasi nilai-nilai Serat Wedhatama dalam pembelajaran sejarah, maka terjadi transformasi nilai kepada siswa untuk memperkuat karakter siswa.

\section{METODE PENELITIAN}

Metode yang digunakan dalam penelitian ini adalah metode Research and Development ( $R \quad n \quad D)$ atau metode penelitian kombinasi. Pengembangan yang digunakan adalah pengembangan model Borg and Gall. Borg and Gall (dalam Sugiono, 2015:35) mengemukakan sepuluh langkah dalam R\&D yang dikembangkan oleh staf Teacher Education Program at Far West Laboratory for Educational Research and Development, dalam mini courses yang bertujuan meningkatkan keterampilan guru pada kelas spesifik. Adapun langkah-langkahnya adalah sebagai berikut: (1) research and information collecting, (2) planning, (3) develop preliminary form a product, (4) preliminary field testing, (5) main product revision, (6) main field testing, (7) operational product revision, (8) operational field testing, (9) final product revision, (10) dissemination and implementation.

Tahap pertama yang dilakukan meliputi research and information collecting adalah pemetaan nilai-nilai etika dan moral dalam Serat Wedhatama melalui proses hermeneutika. Tahap selanjutnya dilakukan analisis kebutuhan pembelajaran sejarah di SMA Negeri 5 
Surakarta. Tahap kedua yaitu planning, berdasarkan data temuan studi pendahuluan dirancang model pembelajaran sejarah berbasis nilai-nilai Serat Wedhatama. Tahap ketiga yaitu mengembangkan bentuk awal model pembelajaran sejarah berbasis nilai-nilai Serat Wedhatama.

\section{PEMBAHASAN}

\section{Nilai-Nilai dalam Serat Wedhatama}

Secara semantik, Serat Wedhatama berasal dari tiga suku kata yaitu: Serat, Wedha, dan Tama. Serat adalah karya yang berbentuk tulisan. Wedha adalah pengetahuan atau ajaran dan tama berasal dari kata utama yang artinya baik, tinggi atau luhur. Dapat ditarik kesimpulan bahwa Serat Wedhatama adalah sebuah karya yang berisi pengetahuan untuk dijadikan bahan pengajaran dalam mencapai keutamaan dan keluhuran hidup (Wibawa: 2010: 10). Serat Wedhatama merupakan serat piwulang. Serat piwulang adalah karya sastra yang di dalamnya terkandung ajaran moral dan sikap hidup. Serat Wedhatama yang memuat filsafat Jawa merupakan karya Mangkunegara IV. Semula Serat Wedhatama hanya diperuntukkan untuk anak-anak keraton, namun kemudian menyebar ke luar keraton karena ajarannya yang bersifat universal (Vina, 2010: vii).
Pada bait awal Serat Wedhatama dijelaskan tujuan ditulisnya Serat Wedhatama yaitu agar menjadi ajaran budi luhur yang meresap di dalam hati/kalbu, sehingga membentuk watak dan budi pekerti (Sabdacarakatama, 2009: 19). Mangkunegara IV memegang teguh adat istiadat leluhur, sesuai dengan yang dijalankan oleh para leluhurnya, sejak zaman dahulu kala hingga kini. Falsafah hidup Mangkunegara IV adalah wirya, arta dan winasis. Arta adalah harta, winasis adalah kepandaian dan wirya adalah kekuasaan/jabatan, seseorang yang memenuhi tiga falsafah tersebut dihargai oleh orang lain. Namun, jika seseorang tidak memiliki ketiganya menjadi orang yang tidak berguna, hina, pengemis diibaratkan masih berharga daun jati yang sudah kering.

Pada abad ke-19 pengaruh kebudayaan Barat dan Arab sangat kental dan merasuk ke dalam masyarakat Mangkunegaran. Banyak orang jawa yang bergaya Belanda atau orang Jawa yang bergaya Arab. Derasnya arus budaya asing yang masuk diperkuat oleh Ardani (1998: 38) pengaruh kebudayaan asing, baik kebudayaan Barat melalui sistem pemerintahan kolonial Belanda, maupun kebudayaan Arab melalui jalur keagamaan atau perdagangan, merasuk semakin dalam di kalangan masyarakat Jawa. Muncul 
kekhawatiran dalam diri Mangkunegara IV, budaya asing tersebut menghancurkan identitas dan budaya Jawa, sehingga Mangkunegara IV menciptakan berbagai karangan yang menekankan pentingnya mempertahankan ciri-ciri kejawaan dan kemusliman. Kemusliman yang dimaksud disini adalah kemusliman yang dibedakan dengan kemusliman keAraban. Agama Islam dalam pandangannya, perlu diambil intisarinya, bukan tradisi dan kebudayaan Arab dinisbahkan ke dalam Islam.

Setting sosial pada masyarakat Jawa abad ke-19 sebagaimana disebutkan diatas mengalami masa perubahan. Perubahan tersebut mencakup segala aspek baik itu politik, ekonomi maupun dalam sosial budaya. Perubahan yang terjadi antara lokalitas satu dengan lokalitas yang lainnya berbeda. Secara umum faktor yang dominan dalam melatarbelakangi perubahan adalah westernisasi. Westernisasi adalah proses masuknya budaya Barat. Proses westernisasi ini mengubah tatanan masyarakat Jawa dalam segala aspek. Proses westernisasi telah mengubah cara berpikir masyarakat dari berpikir pralogis tradisional menjadi logis rasional dan modern (Wasino, 2014: 3-6). Bagi swapraja Mangkunegara, westernisasi membawa dampak modernisasi dalam bidang ekonomi. Modernisasi dilakukan oleh Mangkunegara IV dengan membangun perkebunan tebu yang dilengkapi dengan industri gula (Wasino, 2008: 45).

Proses westernisasi telah menimbulkan banyak reaksi dari masyarakat bumiputera. Kelompok pertama adalah kelompok yang menentang dan yang kedua adalah kelompok yang bersifat konformis. Kelompok yang menentang masuknya westernisasi melakukan sindiran melalui seni lukis, seni pertunjukan dan karya sastra. Mangkunegaran adalah swapraja yang berhasil menyesuaikan diri dengan keadaan baru pada masa kolonial. Mangkunegara IV berhasil naik tahta (1853-1881) dan berhasil memajukan perkebunan dan industri gulanya. Namun, proses westernisasi yang begitu kuat membuat Mangkunegara IV menulis Serat Wedhatama. Tujuannya adalah ajaran budi luhur itu meresap dalam hati, yang berfungsi membentuk watak dan budi pekerti. Daryono (2007: 45) menjelaskan dalam Serat Wedhatama, seseorang diajarkan untuk bersikap kritis dan kreatif yang termasuk di dalamnya adalah seseorang yang mawas diri dan tahu diri.

Serat Wedhatama berisi ajaran budi luhur dan sebagai pedoman bertingkah laku dalam kehidupan sehari-hari. Nilainilai etika dan moral dalam Serat Wedhatama seperti yang dikemukakan 
Wibawa (2010: 83) adalah hidup sederhana, kasih sayang, tanggung jawab, mengembangkan akal budi, menghayati cinta kasih kepada sesama, rendah hati, tidak sombong, taat beribadah dengan meninggalkan larangan, meraih kedudukan yang baik dengan bekerja tanpa mengenal pamrih di mana pun ia berada, meraih kekayaan dengan bekerja keras, dan menuntut ilmu yang bermanfaat bagi kehidupan dunia. Nilai-nilai yang demikian merupakan nilai moral yang memiliki empat ciri, yaitu berkaitan dengan pribadi manusia yang bertanggung jawab, berkaitan dengan hati nurani, berkaitan dengan kewajiban manusia secara absolut dan tidak bisa ditawartawar, dan bersifat formal.

\section{Nilai-Nilai Etika dan Moral dalam Serat Wedhatama}

Serat Wedhatama yang ditulis oleh Mangkunegara IV terdiri dari 5 pupuh, yaitu Pangkur, Sinom, Pocung, Gambuh dan Kinanthi. Pertama, Pupuh Pangkur membahas tentang figur manusia yang baik dari segi identitas, ilmu dan karakternya. Kedua, Pupuh Sinom membahas tentang hak dan kewajiban spiritual kehidupan manusia. Ketiga, Pupuh Pocung membahas tentang persyaratan dasar hidup seorang manusia berupa pentingnya perjuangan dan pengetahuan untuk mendapatkan kekuasaan, kekayaan dan keahlian untuk menempuh lautan kehidupan di dunia. Keempat, Pupuh Gambuh membahas tentang pemahaman dasar agama Islam untuk mendapatkan kasih dan karunia dari Allah SWT. Terakhir, Pupuh Kinanthi secara umum membahas tentang ajaran dan konsep dalam menjalani kehidupan di dunia ini dengan baik.

Guna memberikan pemahaman yang lebih menyeluruh, secara garis besar tema utama dalam Serat Wedhatama (Widodo, 2016: 522) dapat dilihat dalam rangkuman nilai etika Serat Wedhatama di dalam Tabel 1 berikut.

Tabel 1. Nilai Etika Serat Wedhatama

\begin{tabular}{ccl}
\hline Bait & Pupuh & \multicolumn{1}{c}{ Tema dalam Teks } \\
\hline $1-14$ & Pangkur & $\begin{array}{l}\text { Pada pupuh Pangkur menjelaskan tentang identitas, pentingnya ilmu pengetahuan, } \\
\text { karakter dan bagaimana menjadi seorang figur yang baik. }\end{array}$ \\
\hline $1-18$ & Sinom & Menjelaskan tentang hak dan kewajiban dan dasar-dasar spiritual untuk hidup. \\
\hline $1-15$ & Pocung & $\begin{array}{l}\text { Pentingnya manusia dalam cosmos, yaitu pentingnya berjuang untuk mendapatkan } \\
\text { pengetahuan untuk mendapatkan wirya (power), arta (kekayaan), dan wasis (skill) sebagai } \\
\text { persyaratan dasar kehidupan. }\end{array}$ \\
\hline $1-35$ & Gambuh & $\begin{array}{l}\text { Menjelaskan tentang pemahaman yang mendalam agama Islam, formula yang dikenal } \\
\text { sebagai sembah catur, atau "empat jenis penghormatan", dijelaskan (tubuh, pikiran, jiwa, } \\
\text { dan perasaan) sebagai cara untuk mendapatkan kasih karunia Allah }\end{array}$ \\
\hline $1-18$ & Kinanthi & Berisi ajaran atau konsep tentang bagaimana menjalani hidup dengan baik \\
\hline
\end{tabular}


Kandungan nilai-nilai yang berkaitan dengan etika dalam Serat Wedhatama dapat dilihat dari beberapa petuah berikut ini:

a. Ajaran untuk menjadi orang yang tidak lemah budinya dan tumpul perasaannya (tan mikani rasa), sebab orang yang lemah budinya dan tumpul perasaannya, meskipun sudah tua, ia bagaikan sepah tebu dan ketika dalam pertemuan sering bertindak memalukan (gonyak-ganyuk nglelingsemi) dapat dilihat pada pupuh pangkur bait ke-2.

b. Sebaiknya mempelajari ilmu sejati, yang membuat nyaman di hati. Ilmu ini mengajarkan agar menerima dengan senang hati jika dianggap bodoh (bungah ingaran cubluk) dan tetap gembira jika dihina (sukeng tyas yen den ina) dapat dilihat dalam pupuh pangkur bait ke 5 .

c. Jangan bertindak semaunya sendiri (nggugu karepe priyangga). Sifatnya, jika berbicara tanpa dipikirkan lebih dahulu, tidak mau dianggap bodoh, dan mabuk ujian dapat dilihat dalam pupuh pangkur bait 3-4.

d. Petuah agar berguru pada kebaikan (purita kang patut), serta dapat menempatkan diri (traping angganira) dan mematuhi tatanan negara (angger ugering keprabon) dapat dilihat dalam pupuh pangkur bait ke 10-11.

e. Jangan berperilaku seperti perilakunya orang yang dungu, yang bualannya tidak karuan dan tidak masuk akal (ngandhar-adhar

angendhukur,

kandane nora kaprah). Orang yang dungu itu selalu sombong (anggung gumrunggung) ingin selalu di puji (ugungan sedina-dina). Sebaliknya, jadilah orang yang bijaksana, yang dalam menanggapi orang yang dungu dengan cara yang halus (sinamun ing samudana) dan baik (sasadon ing adu manis) dapat dilihat dalam pupuh pangkur 3-5.

f. Petuah agar berguru tentang kebaikan (puruita kang patut), serta dapat menempatkan diri (traping angganira) dan mematuhi tatanan negara (angger ugering keprabon) dapat dilihat pada pupuh Pangkur bait ke 10-11.

g. Ajaran bahwa budi yang baik itu biasanya pandai bergaul dengan berbagai kalangan (bangkit ajur ajer). Meskipun pengetahuannya yang benar berbeda dengan pendapat orang lain, ia bersikap baik, sekedar untuk menyenangkan hati orang lain (mung ngenaki tyasing lyan). Oleh karena itu hendaknya dapat berpura-pura bodoh (den bisa mbusuki ujaring janmi) dapat dilihat pada pupuh Kinanthi bait ke 9598.

Serat Wedhatama menekankan pentingnya pendidikan bagi setiap orang/etika yang dimiliki oleh setiap individu. Pentingnya pengembangan akal, pikiran, rasionalitas, atau intelektualitas untuk bekal hidup sehari-hari. Etos belajar juga ditekankan, dimana dijelaskan 
pencapaian ilmu itu harus dijalani dengan suatu proses (ngelmu iku kelakone kanthi laku) dan dimulai dengan kemauan yang kuat (lekasane klawan kas). Untuk mengangkat kedudukan manusia, seseorang harus memiliki tiga pegangan yaitu pangkat, harta, dan kepintaran (wirya harta tri winasis). Jika seseorang tidak memiliki satu pun diantara ketiganya, maka tidak ada artinya sebagai manusia, bahkan lebih berharga dari daun jati kering. Seseorang hendaknya berbekal pada ingat dan waspada (eling lan waspada, awas lane ling)

Serat Wedhatama mengajarkan agar orang jangan sampai bertindak kurang sopan santun dalam pertemuan, sehingga memalukan. Demikian juga bertindak semaunya sendiri, jika berbicara tanpa dipikirkan lebih dahulu, tidak mau dianggap bodoh, dan mabuk pujian. Seseorang hendaknya dapat menempatkan diri dan mematuhi tatanan negara (angger ugering keprabon). Orang yang baik budinya itu biasanya pandai bergaul dengan berbagai kalangan (bangkit ajur-ajer).

Nilai Moral dalam Serat Wedhatama

Ajaran moral yang diajarkan dalam Serat Wedhatama dapat dilihat pada kutipan-kutipan di bawah ini:

"Uger lugu, den ta mrih pralebdeng kalbu. Yen Kabul kabula. Ing drajat kajating urip. Kaya kang wus winahyeng sekar srinata" (asal benar-benar, dalam usahanya meningkatkan pikiran, bila terkabul, terbukalah dalam derajat keinginan hidup, seperti yang termaktub dalam tembang ini).
Bait di atas mengajarkan seseorang harus jujur pada diri sendiri. Ilmu diri tidak dapat diperoleh dari luar. Ilmu diri harus dilakukan dengan usaha, yaitu dengan meningkatkan pikiran. Usaha apapun yang telah dilakukan hanya diri sendiri yang tahu. Apabila usaha yang dilakukannya berhasil, dengan kesadaran diri, mendekatkan diri dengan Tuhan dan alam sekitar, hidup bisa menjadi lebih bahagia, lebih indah, lebih berwarna dan berirama (Supanti, 2008:200).

"Mangkono janma utama, tuman tumanem ing sepi, ing saben rikala mangsa, masah amemasuh budi, laire anetepi, ing reh kasatriyanipun, susilo anor raga, wignya met tyasing sesame, yeku aran wong barek berag agama". (Demikianlah manusia utama, gemar dalam ketenangan, di saat-saat tertentu, mempertajam dan membersihkan budi, bermaksud memenuhi tugasnya sebagai satria, berbuat susila rendah hati, pandai menyejukkan hati pada sesame, itulah sebenarnya yang menghayati agama).

Nulada laku utama/ tumraping wong tanah Jawi. Wong Agung ing Ngeksiganda/ Panembahan Senopati. Kapati amarsudi/ udaning hawa lan nepsu. Pinesu tapa brata/ Tanapi ing siang ratri. Ama-mangun karyenak tyasing sasama. (Contohlah perbuatan yang sangat baik, bagi penduduk di tanah Jawa, dari seorang tokoh besar Mataram, Panembahan Senopati, berusaha dengan kesungguhan hatinya, mengendapkan hawa nafsu, dengan melakukan olah samadi, baik siang dan 
malam, mewujudkan perasaan senang hatinya bagi sesama insan hidup)

Serat Wedhatama adalah serat yang berisi ajaran budi luhur dan sebagai pedoman bertingkah laku dalam kehidupan sehari-hari. Nilai-nilai moral dalam Serat Wedhatama seperti yang dikemukakan Wibawa (2010: 83) adalah hidup sederhana, kasih sayang, tanggung jawab, mengembangkan akal budi, menghayati cinta kasih kepada sesama, rendah hati, tidak sombong, taat beribadah dengan meninggalkan larangan, meraih kedudukan yang baik dengan bekerja tanpa mengenal pamrih di mana pun ia berada, meraih kekayaan dengan bekerja keras, dan menuntut ilmu yang bermanfaat bagi kehidupan dunia. Nilai-nilai yang demikian merupakan nilai moral yang memiliki empat ciri, yaitu berkaitan dengan pribadi manusia yang bertanggung jawab, berkaitan dengan hati nurani, berkaitan dengan kewajiban manusia secara absolut dan tidak bisa ditawar-tawar, dan bersifat formal.

Adapun nilai-nilai Serat Wedhatama yang digunakan dalam model pembelajaran sejarah berbasis Serat Wedhatama adalah rendah hati, tanggung jawab, kerja keras, kerjasama, menghormati orang lain, integritas dan toleransi. Nilai-nilai tersebut merupakan modal dasar yang seyogyanya dimiliki oleh seorang manusia dalam kehidupan sehari-hari dan pergaulan di masyarakat

\section{Pembelajaran Sejarah di SMA Negeri 5 Surakarta}

Berdasarkan studi pendahuluan di SMA Negeri 5 Surakarta, diketahui bahwa kompetensi guru dalam implementasi kurikulum sejarah 2013 sudah cukup baik. Namun, ada beberapa point-point yang masih dianggap kurang, antara lain:

a. Model-model yang digunakan selama ini oleh guru, masih menitikberatkan pada mentransfer pengetahuan (transfer of knowledge) dengan ceramah sehingga pembelajaran sedikit berpusat pada guru (teacher centered learning), kurang menekankan pada ranah afektif khususnya dalam hal menekankan etika dan moral pada siswa.

b. Melalui pengamatan yang dilakukan di dalam kelas, maupun di luar kelas dapat dikatakan bahwa etika dan moral peserta didik masih tergolong rendah.

c. Pemahaman guru yang kurang terhadap konsep model pendekatan klarifikasi nilai (VCT) dan implementasinya. Dalam hal ini pendekatan VCT berfungsi untuk membantu siswa menemukan dan mengaktualisasikan nilai-nilai etika dan moral yang tidak bertentangan dengan norma/nilai/aturan yang berlaku di lingkungan sekolah, masyarakat dan negara.

d. Kurangnya pemahaman dan keterampilan guru dalam mendesain pembelajaran sejarah yang 
mengintegrasikan nilai-nilai etika dan moral, padahal komponen ini sangat penting sebagai upaya menanamkan karakter pada peserta didik untuk mewujudkan generasi muda yang siap bersaing dalam kancah global.

Serat Wedhatama merupakan warisan budaya yang hingga kini masih dikenal sebagian masyarakat Jawa. Proses pewarisan nilai-nilai bisa melalui sistem pendidikan formal dan juga jalur kultural. Dalam globalisasi budaya, budaya Jawa dapat dijadikan sebagai alternatif bagi masyarakat dalam menanamkan nilai-nilai luhur bangsa Indonesia.

Pada saat nilai-nilai baru tidak dapat memberikan sesuatu yang diharapkan, maka orang akan kembali menoleh pada nilai-nilai lama yang ditinggalkan. Dalam Serat Wedhatama terkandung nilai-nilai yang adiluhung. Dengan demikian peserta didik menganggap perlu mengambil nilainilai dalam Serat Wedhatama untuk diaplikasikan dalam kehidupan sehari-hari baik dalam kehidupan di sekolah, masyarakat, maupun dalam bernegara.

Pada dasarnya, implementasi nilai-nilai dalam Serat Wedhatama dapat mengangkat budaya lokal (masyarakat Jawa), sehingga peserta didik diajak untuk memahami kebudayaan sendiri yang selama ini telah berada di sekitarnya. Keterbatasan guru dan siswa dalam memaknai serat, mengakibatkan guru dan siswa menjadi kurang berminat untuk mempelajari peninggalan pujangga Jawa yang kaya nilai.
Dengan demikian, diperlukan sebuah terobosan baru dalam upaya melestarikan budaya lokal, khususnya dalam mempelajari nilai-nilai etika dan moral, yaitu melalui pengembangan model pembelajaran yang berbasis pada nilai-nilai Serat Wedhatama.

\section{Draf Model Pembelajaran Sejarah Berbasis Nilai-Nilai Serat Wedhatama}

Dalam penelitian ini produk yang dihasilkan adalah model pembelajaran sejarah berbasis Serat Wedhatama (Model Sesratama). Model pembelajaran ini diciptakan sebagai solusi untuk meningkatkan etika dan moral pada siswa SMA. Penyusunan draf model pembelajaran ini berpijak pada hasil kajian pustaka, dengan cara memadukan kesesuaian karakteristik model yang dikembangkan. Dasar penyusunan yang digunakan menjadi acuan adalah sintaks, sistem sosial, prinsip reaksi, sistem pendukung, dampak pengiring.

Fokus penelitian ini adalah memperbaiki dan memberdayakan model pembelajaran sejarah berbasis Serat Wedhatama untuk meningkatkan etika dan moral pada siswa. Etika dan moral merupakan landasan utama bagi siswa untuk membentuk karakter. Pengembangan model pembelajaran berbasis nilai-nilai yang terkandung dalam Serat Wedhatama diharapkan dapat memberikan stimulus kepada siswa untuk memahami nilai-nilai luhur warisan bangsa Indonesia dan mengimplementasikannya dalam segala 
sendi kehidupan bermasyarakat dan

bernegara. Selain itu, melalui

pengembangan model pembelajaran

sejarah berbasis Serat Wedhatama ini

diharapkan nantinya peserta didik dapat

memiliki dua kompetensi yang menjadi tujuan dalam penelitian ini, yaitu etika dan moral.

\section{Struktur}

Struktur Sintaks Model Pembelajaran

$\begin{array}{llll}\text { Sejarah Berbasis } & \text { Nilai-Nilai } & \text { Serat } \\ \text { Wedhatama (Model } & \text { Sesratama) } & \text { dapat }\end{array}$

dilihat pada rangkuman Tabel 2 berikut.

Tabel 2. Struktur Model Sesratama

\begin{tabular}{|c|c|}
\hline Tahapan & Kegiatan \\
\hline PENDAHULUAN & $\begin{array}{l}\text { 1. Mengawali pembelajaran dengan berdoa dan memberi salam } \\
\text { 2. Mempersiapkan kelas agar lebih kondusif untuk memulai proses kegiatan belajar mengajar } \\
\text { (kerapian, kebersihan ruang kelas, menyediakan media dan alat serta buku yang diperlukan) } \\
\text { 3. Memantau kehadiran dengan mengabsen peserta didik } \\
\text { 4. Mereview materi minggu lalu dan mengajukan pertanyaan tentang materi yang terkait } \\
\text { dengan materi yang akan disampaikan. } \\
\text { 5. Menyampaikan lingkup dan teknik penilaian yang akan digunakan } \\
\text { 6. Menyampaikan topik pertemuan pada hari ini } \\
\text { 7. Memberikan penjelasan singkat tentang permasalahan degradasi moral yang terjadi } \\
\text { 8. Memarang. }\end{array}$ \\
\hline INTI & 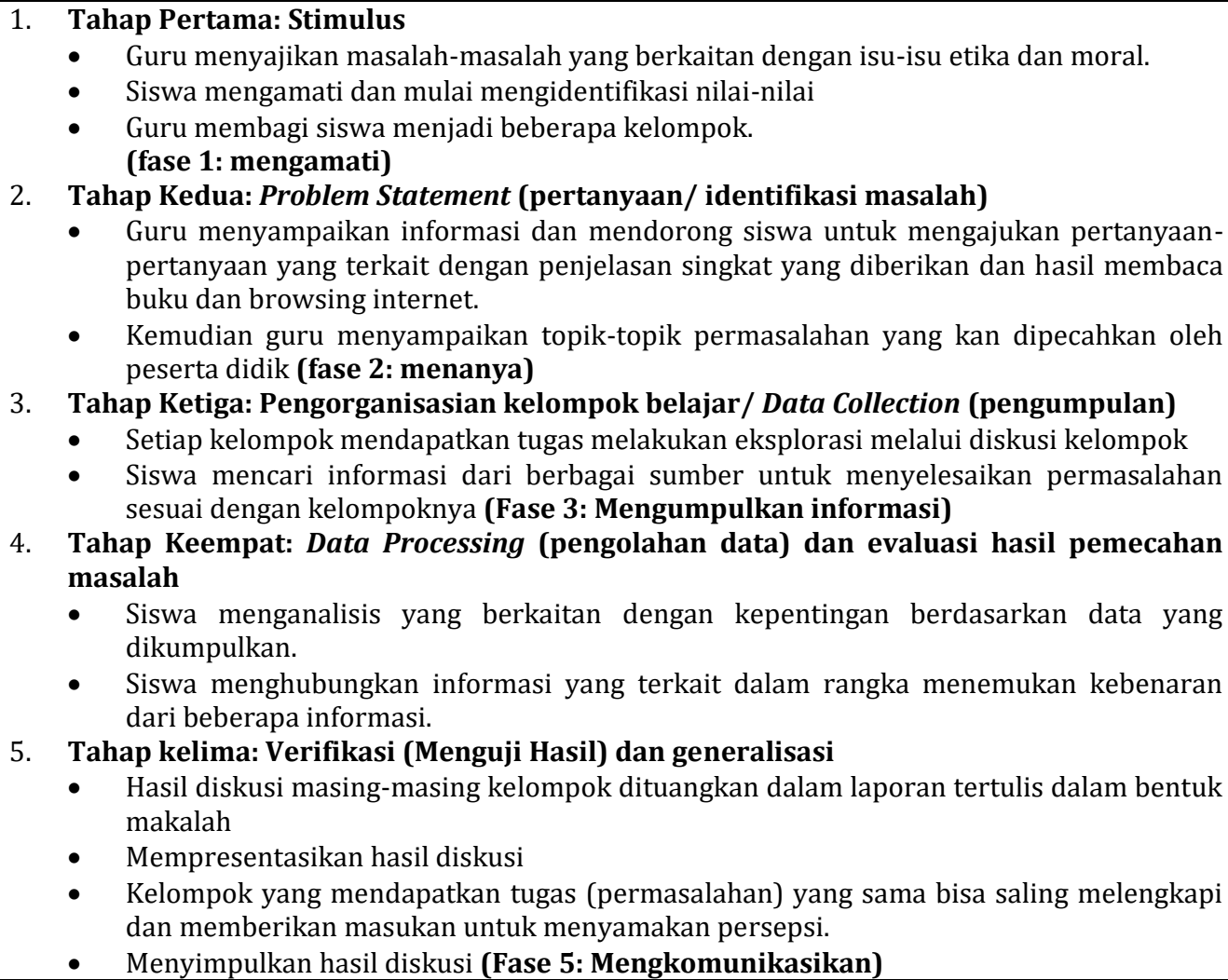 \\
\hline PENUTUP & $\begin{array}{l}\text { 1. Guru bersama siswa secara bersama-sama membuat kesimpulan materi pembelajaran. } \\
\text { 2. Guru melakukan evaluasi untuk mengukur ketercapaian pembelajaran } \\
\text { 3. Guru bersama siswa melakukan refleksi tentang pelaksanaan pembelajaran } \\
\text { 4. Siswa diminta untuk mengumpulkan essay tentang etika dan moral. } \\
\text { 5. Guru menyampaikan materi yang akan disampaikan pada pertemuan yang akan datang } \\
\text { 6. } \\
\text { Kegiatan diakhiri dengan salam }\end{array}$ \\
\hline
\end{tabular}




\section{Sistem Sosial}

Sistem sosial pada model Sesratama bersifat kolaboratif, jadi peran guru disini tetap menjadi mediator, fasilitator, dan motivator dalam setiap kegiatan pembelajaran yang dilakukan. Hal yang sangat penting untuk dinilai adalah mengenai kreativitas peserta didik serta prestasi belajar peserta didik dalam memecahkan masalah. Disamping itu sistem sosial yang dikembangkan dalam penelitian ini yaitu: 1) menanamkan etika dan moral pada siswa, 2) menanamkan sikap kooperatif pada siswa, 3) menciptakan pembelajaran yang aktif, komunikatif, kreatif dan menyenangkan.

\section{Prinsip Reaksi}

Dalam pengelolaan pembelajaran yang dijalankan oleh pendidik adalah memberikan kemudahan pada peserta didik dalam kegiatan pembelajaran untuk meningkatkan pemahaman, kreativitas dan prestasi belajar peserta didik. Di samping itu pendidik juga sebagai fasilitator, pembimbing kelompok sekaligus motivator agar peserta didik lebih aktif dan bersemangat dalam mengikuti proses pembelajaran.

\section{Sistem Pendukung}

Sistem pendukung dalam pengembangan model ini adalah 1) masalah tentang krisis dan dekadensi moral, 2) RPP dan Model Sesratama, 3) lembar kerja siswa sekaligus pedoman dalam implementasi klarifikasi nilai, dan 4) lembar evaluasi

\section{Dampak Pengiring}

Model Sesratama dirancang untuk meningkatkan prestasi belajar, kemampuan berpikir kritis dalam memecahkan segala macam bentuk persoalan dan dalam mengklarifikasi nilai yang relevan dengan kehidupan sehari-hari. Siswa diharapkan dapat lebih memahami etika dan moral bangsa Indonesia.

\section{PENUTUP}

Era globalisasi menyebabkan benturan kebudayaan, antara budaya asing dan budaya bangsa. Hal ini berdampak pada hilangnya jati diri bangsa. Untuk mengantisipasi hal tersebut diperlukan dekonstruksi budaya yang berbasis pada budaya adiluhung bangsa. Serat Wedhatama adalah salah satu karya sastra yang di dalamnya terdapat nilai-nilai dan falsafah hidup orang Jawa. Dekonstruksi Serat Wedhatama diperlukan untuk memperoleh indigenous moral yang berbasis pada budaya lokal. Indigenous moral kemudian dihabituasikan dalam bidang pendidikan sebagai strategi character building untuk generasi muda. Nilai-nilai dalam Serat Wedhatama diimplementasikan dalam model pembelajaran sejarah. Melalui model pembelajaran Sejarah berbasis nilai-nilai Serat Wedhatama diharapkan mampu meningkatkan etika dan moral pada peserta didik.

Proses draf model pembelajaran sejarah berbasis nilai-nilai Serat Wedhatama dilakukan dengan melalui tiga 
tahap. Pertama, research and information collecting yaitu dengan pemetaan nilai-nilai etika dan moral dalam Serat Wedhatama melalui proses hermeneutika. Selanjutnya dilakukan analisis kebutuhan pembelajaran sejarah di SMA Negeri 5 Surakarta. Kedua, planning berdasarkan data temuan studi pendahuluan dirancang model pembelajaran sejarah berbasis nilai-nilai Serat Wedhatama. Ketiga, mengembangkan bentuk awal model pembelajaran sejarah berbasis nilai-nilai Serat Wedhatama.

\section{REFERENSI}

Abdurahman, D. (2007). Metodologi Penelitian Sejarah. Jakarta: Logos Wacana Ilmu

Ardani. (1998). Al- Qur'an dan Sufisme Mangkunegara IV: Studi Serat-Serat Piwulang. Yogyakarta: Dana Bhakti Wakaf.

Daliman. (2012). Pengantar Filsafat Sejarah. Yogyakarta: Penerbit Ombak.

Daryono. (2007). Etos Dagang Orang Jawa: Pengalaman Mangkunegara IV. Yogyakarta: Pustaka Pelajar.

Garg, B. (2007). Teaching of History. New Delhi: Rajat Publication.

Garvey, B. \& Mary. (2015). Model-Model Pembelajaran Sejarah di Sekolah Menengah. Yogyakarta: Ombak.

Kochar. (2008). Pembelajaran Sejarah. Jakarta: Grasindo

Kuntowijoyo. (2005). Pengantar Ilmu Sejarah. Yogyakarta: Bentang Pustaka.

Latief, Y. (2009). Menyemai Karakter Bangsa. Jakarta: Kompas

Lickona, T. (2008). Educating for Character. New York: Bantam Book.
Sabdacarakatama. (2010). Serat Wedhatama. Yogyakarta: Narasi

Zubaedi. (2009). Desain Pendidikan Karakter: Konsepsi dan Aplikasinya dalam Lembaga Pendidikan. Jakarta: Kencana Prenada Media Group.

Setiawan, A. (2016). Koran Tempo. Menanti Gebrakan Hilmar Farid, Jumat 15 Januari 201, hlm. 11).

Supanta. (2008). Serat Wedhatama Karya K.G.P.A.A Mangkunegara IV Serta Sumbangannya Terhadap Pendidikan: Kajian Struktur dan Nilai Edukatif. Disertasi. UNS.

Wasino. (2014). Modernisasi di Jantung Budaya Jawa: Mangkunegaran 18961944. Jakarta: Gramedia. (2008). Kapitalisme Bumi Putera. Yogyakarta: LKIS

Wibawa, S. (2010). "Nilai-Nilai Moral dalam Serat Wedhatama dan Pendidikan Budi Pekerti", Edisi Khusus Dies Natais UNY, Vol 1, Th. XXIV, No 3 (Mei, 2010): 7284, dapat diakses di alamat situs: http://journal.uny.ac.id/index.php/cp/ article/view/237.

Widodo, S. T. (2016). The Concept of a Social Organism: The Response of Javanese Society to Modernism in the Serat Wedhatama by Kanjeng Gusti Pengeran Adipati Arya (K.G.P.A.A) Mangkunegara IV. Journal Sciences \& Humanities, 24 (1), 519-526. 